\title{
Four decades of Groningen production and pricing policies
}

\author{
A.F. Correljé ${ }^{1,2} \&$ P.R. Odell ${ }^{3}$ \\ 1 Corresponding author; e-mail: correlje@few.eur.nl \\ 2 Erasmus University Rotterdam, Applied Economics / Erasmus Centre for Environmental \\ Studies, P.O.Box 1738, 3000 Rotterdam \\ ${ }^{3}$ Emeritus Professor, Erasmus University Rotterdam, Applied Economics
}

Manuscript received: 2 Jun 1999; accepted in revised form: 14 Jul 2000

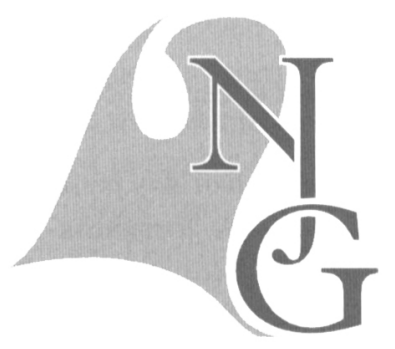

\begin{abstract}
This paper deals with production and pricing policies for the Groningen gasfield. It will provide an evaluation of the past and a view to its future in a liberalized European gas market. The lifelong production potential and high productivity of the Groningen gasfield is unique. The extremely low-cost field is also unique in the sub-optimal manner in which it has been exploited over the whole of its forty year life to date. Its initial monopolistic situation in the West European energy economy created an opportunity for its development to be limited to production levels, whereby super-normal profits were generated on high value sales at the cost of consumers' welfare.

The breach in the monopoly, through competition from Soviet gas, readily able to undercut Groningen prices, posed a serious threat both to unit values and market expansion. Fortunately, the fortuitous 1973/4 international oil supplies and pricing crisis restored Groningen's fortunes. Following the upward price adjustments for foreign sales, the stage was set for achieving high company profits and massive government revenues. Dutch society in a broader sense benefited only indirectly through government tax expenditures. Again, energy consumers' welfare gains were ignored.

This remains the essence of the situation, pending agreement on the introduction of the liberalized market to meet EU directives. Currently the Dutch gas regime and policy objectives are being adjusted to the requirements of operating in a liberalized market. These changes recognize: first, the invalidity of the government's long-held fears for gas scarcity in such a way, that the earlier steps to restrict both foreign and national sales have been abandoned, and second, the need to reinstate Gasunie as an active, rather than a passive, player in the European gas market, in which other participants have subverted Gasunie's earlier dominance.

The second part of the paper will examine, whether and how these changes can be reconciled with the core elements of the Dutch gas policy, i.e. state and private revenues, co-ordination of supply and production, the 'small fields policy' and the balancing role of the Groningen field. The liberalization of the European gas market, together with changes in the pattern of supply and demand and stated Dutch policy objectives of energy policy may give rise to conflicts between the interests of the Dutch State, the owners of the field and, again, the consumers.
\end{abstract}

Keywords: Groningen gas, pricing policy, energy economy, Dutch society, liberalization

\section{Introduction}

As shown in a succession of papers published at regular intervals over the period since 1969 (Odell, 1969; $1975 ; 1979 ; 1984 ; 1988 ; 1992 ; 1995 ; 1997$; Correljé, 1998), we concur with the view expressed in the title given to this conference, that Groningen has been a catalyst with respect to the evolution of the European gas industry. In the first part of this paper, we evaluate the way, in which this catalyst worked - for better and for worse - in the past; while in the second part an analysis is made of the impact of fundamental policy changes, at both the European Union and the national levels, on the prospects for Groningen gas. 


\section{Groningen's Past}

Groningen was an extraordinary phenomenon, both in its own right as a super-giant gasfield and in terms of its mode and pattern of exploitation. Our concern is with the politico-economic aspects of the latter, though also involving the issue of the public presentation of the former with particular respect to the size and productivity of the field and of the costs of exploiting it.

Given its discovery within a unified concession (except, of course, for the small part of the field underlying German territory) operated by a single company (Nederlandse Aardolie Maatschappij B.V., NAM, owned $50 \%-50 \%$ by respectively Shell and Esso) plus a state interest, there was a near-perfect monopoly, especially in the context of an absence of any significant alternative sources of gas within a radius of a thousand kilometers at the time of its discovery and early development.

Its existence as a natural monopoly was thus never in question and this, in combination with the position of the NAM in the Netherlands, established the framework for the supply side of its exploitation. On the demand side the conditions were equally propitious: Groningen was located close to the center of one of the world's most energy intensive consuming regions, with, in addition, the two most important suppliers of hydrocarbons to most of the market area being the two companies, which had discovered the field. Given these conditions, the creation of a set of national or regional monopolistic transporters and another set of monopsonistic distributors and marketers of the potential gas supply from Groningen was axiomatic.

This resulted in the establishment of N.V. Nederlandse Gasunie, which had the exclusive right to purchase, transport, market and sell natural gas produced in the Netherlands. Gasunie's shareholders are the Dutch state $(50 \%)$ and Shell and Exxon (25\% each) (for details see Taverne in this issue).

Monopoly plus monopsony was thus imposed and implemented on the emerging national gas industry. This was achieved in an ordered way - as per the system illustrated in figure 1 - and within which the price of the gas offered (the volume of which was initially restricted to well below the competitive optimum level) was related to the opportunity costs in the markets. At the period of extensive introduction of the gas to the markets (see Fig. 1), Europe consisted of a set of relatively high-priced energy markets aris- ing from a situation of highly protected indigenous coal and a less than fully competitive supply of oil products. The netback value of the Groningen gas marketed was thus a multiple of the very low long-run supply price of the commodity, with consequential super-normal profits for the producers and generous revenues for the state. Energy consumers were, of course, the losers: but this was largely unrecognized by them in the context of the ordered system imposed. They were, in any case, used to high energy prices. Gas, in effect, was offered on a take-it or leaveit basis as a so-called premium fuel at so-called "competitive" prices, so that no lower prices were attainable. Monopoly power was effectively exercised.

Monopolies, however, are inherently fragile and, as shown in figure 2, alternative suppliers emerged on to the European gas scene. In the case of the UK, with its newly-found offshore gas fields, this happened even before the planned Dutch exports could be implemented. This sequence of events, whereby the planned Dutch gas exports to the UK market in 1965 were excluded, led to the physical separation of the British and mainland European systems for 30 years. It also meant, that the nature of the British gas supply system developed in a completely different way from that generated elsewhere in Europe by the Groningen phenomenon. Had events been otherwise, the privatization and liberalization of the British market may not have occurred and thus not have had the strong demonstration effect on reorganization of the gas industry in the rest of Europe, as now in progress.

Elsewhere on the mainland of Europe, initial imports of pipelined Soviet gas and of North African LNG were made available at locations, where prices could be competitive with those for Groningen gas. Such competitive forces were, however, soon restrained by the enhanced opportunities for selling gas, which were created by an important external development, viz. the oil price shock of 1973/4. Gas consumers' hopes, that gas would be offered as an alternative lower-priced energy source were, however, quickly thwarted as the steeply upward sloping demand curve - in the context of fears over the security of oil supplies led to a tightening of the oil price/gas price links, so enabling gas producers' profits and host-governments' revenues to be boosted. The ordered system, originally established to market Groningen gas, was now made more extensive and intensive across much of the continent - to the great advantage not only of the various suppliers now acting oligopolistically, but also to that of regional monopsonistic distributors which achieved high sales margins. 

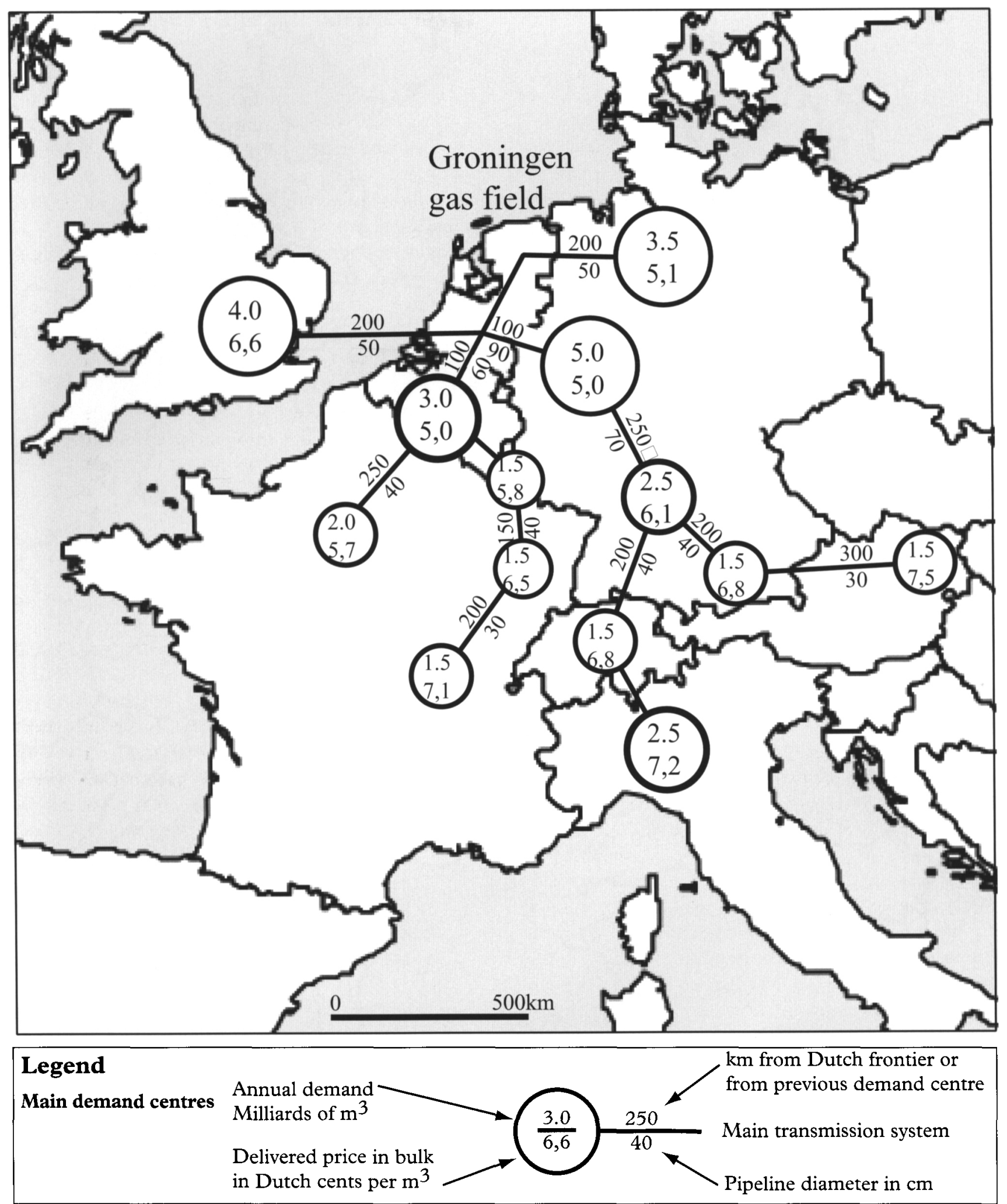

Fig. 1. Groningen gas: a 1969 estimate of Gasunie gas export as planned for 1975 (after Odell 1969, p.12).

But not even these structured restraints on the pace of gas developments satisfied the Dutch gas supply industry. Another factor was now introduced to curb demand growth and to add to upstream profits, viz. the "declaration" of gas to be a scarce commodity. This eminently and demonstrably false vision of the future of gas availabilities (even at the time, let alone in retrospect, Odell, 1973) led to actions - both at various national and the European levels - to constrain gas demand, while Dutch policy deliberately sought to constrain supply (Odell, 1989). 


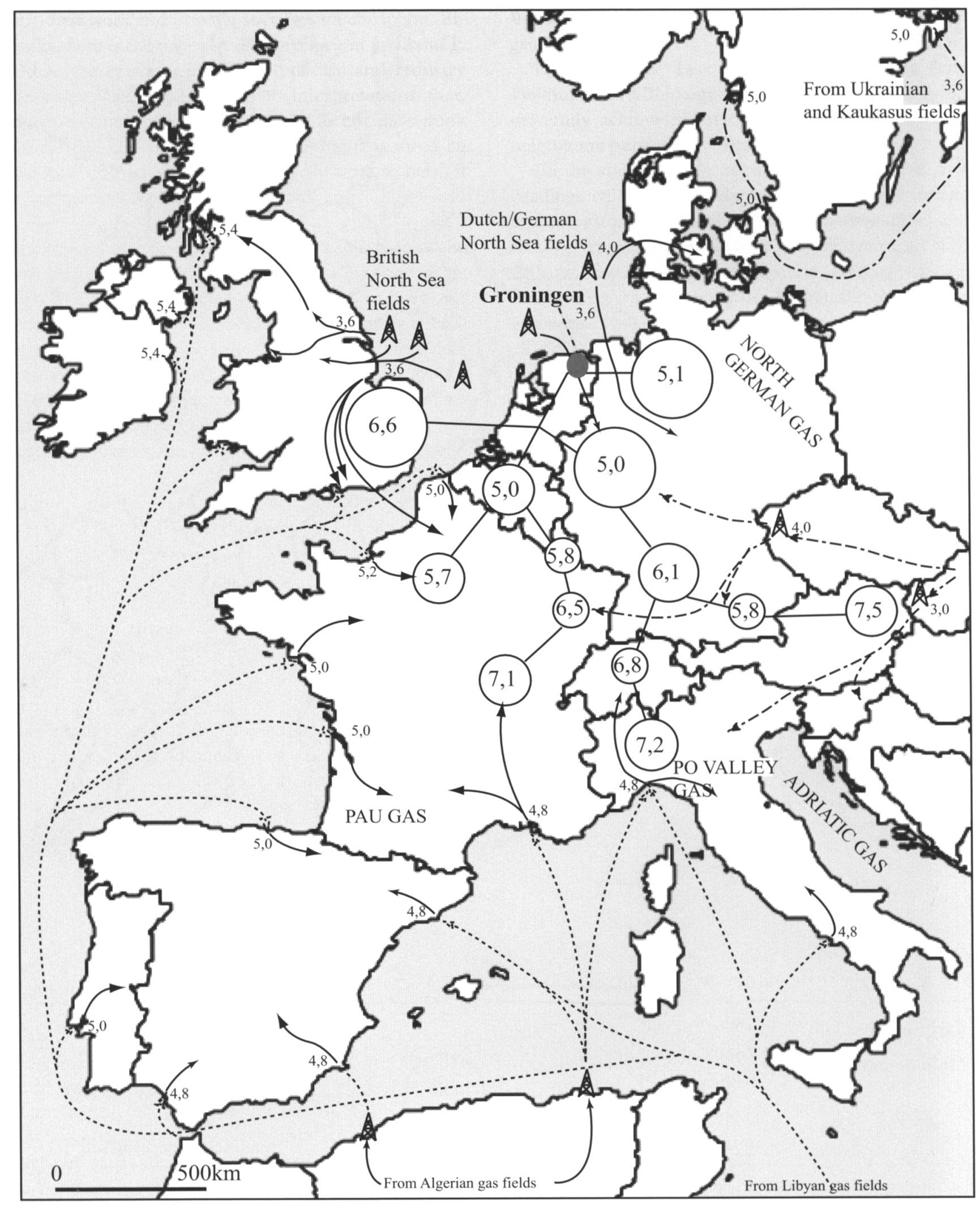

Legend Groningen gas planned marketing network from fig. 2, showing delivered price in Dutch cents per $\mathrm{m}^{3}$ New alternative supplies of gas.

$$
\begin{array}{ll}
\text { pipelines } \\
\text { Algerian and Libyan } \\
\text { liquified gas }
\end{array}
$$

Fig. 2. Competition for Groningen gas in the 1970's (Odell 1969, p.17). 
Whilst demand growth constraint was successfully achieved post-1976 - as can be clearly seen from the data in Table 1 - gas suppliers, except for the Dutch, sought to expand their markets. This involved much enhanced Soviet exports - with Ruhr gas and SNAM as the facilitators and beneficiaries; increased Norwegian investments in both field developments (notably the new super-giant field, Troll) and in gas delivery systems to the mainland of Europe; the expansion of Algerian potential through the Trans-Mediterranean pipeline to Italy and as LNG to market areas hitherto entirely dependent on Dutch gas (most notably Belgium); and, finally, the belated decision by the UK to inter-connect its hitherto isolated gas system with that of mainland Europe.

These supply-side reactions to the Dutch decisions to limit supplies as a matter of policy served to undermine not only the dominance in the European gas system previously secured by Groningen gas, but also the role of NAM/Gasunie as the leading actors in the gas supply system. In terms of the Dutch contribution to mainland Western Europe's demand (outside the Netherlands itself), the decline was steep and continuing - as shown in Table 2 - from almost $54 \%$ in 1971 to only $36 \%$ in 1981 and to less than $20 \%$ by 1997. Groningen, in particular, as in effect a supplier of last resort (given the preference extended by the Dutch government to small fields' exploitation) was even more significantly affected: so much so, in fact, that it can be described as having lost its role as a catalyst in the system. In spite of its ultra-low costs of production, it became, as with Saudi Arabia - the lowest cost oil producer in the international oil system - the swing producer, responding to, rather than initiating, changes.

Eventually, though already much too late to restore the status quo ante, the fallacy of gas scarcity was final-

Table 1. Natural Gas Demand in Western Europe, 1961-1996.

\begin{tabular}{|c|c|c|c|c|}
\hline \multirow[t]{2}{*}{ Year } & \multirow{2}{*}{$\begin{array}{l}\text { No. of } \\
\text { Countries } \\
\text { Using Gas }\end{array}$} & \multicolumn{2}{|l|}{ Total Use } & \multirow{2}{*}{$\begin{array}{l}\text { Gas Use as \% } \\
\text { of Energy Use }\end{array}$} \\
\hline & & $\times 10^{9} \mathrm{~m}^{3}$ & $\%$ increase & \\
\hline 1961 & 5 & 16 & - & 1.8 \\
\hline 1966 & 7 & 25 & $77.8 \%$ & 3.3 \\
\hline 1971 & 8 & 106 & $416.0 \%$ & 9.7 \\
\hline 1976 & 10 & 183 & $72.6 \%$ & 13.4 \\
\hline 1981 & 11 & 200 & $9.3 \%$ & 14.7 \\
\hline 1986 & 15 & 218 & $9.0 \%$ & 15.2 \\
\hline 1991 & 15 & 270 & $23.9 \%$ & 19.4 \\
\hline 1996 & 17 & 344 & $27.4 \%$ & 21.5 \\
\hline
\end{tabular}

Source: BP Gas statistics, various years.
Table 2 Dutch Gas Exports in $109 \mathrm{~m} 3$ to Mainland W. European Markets, 1971-1996.

\begin{tabular}{llll}
\hline Year & $\begin{array}{l}\text { Dutch Gas } \\
\text { Exports }\end{array}$ & $\begin{array}{l}\text { Demand in } \\
\text { the Markets }\end{array}$ & $\begin{array}{l}\text { \% of Dutch Gas } \\
\text { to the Markets }\end{array}$ \\
\hline 1971 & 25.2 & 46.7 & 54.0 \\
1976 & 39.4 & 93.8 & 42.0 \\
1981 & 43.0 & 118.0 & 36.4 \\
1986 & 35.3 & 131.7 & 26.8 \\
1991 & 30.9 & 166.3 & 18.6 \\
1996 & 45.8 & 212.1 & 21.6 \\
1997 & 40.1 & 210.7 & 19.1 \\
\hline
\end{tabular}

Source: BP Gas statistics, various years.

ly discarded. As shown in figure 3 , the cumulative use of Groningen gas failed to draw down the volumes of declared, remaining recoverable reserves: in part because of the factors noted above, but in part also because of the guarantees of volume and price extended to production from Dutch fields other than Groningen, in a policy which, yet again, was deliberately suboptimal in economic terms (Correljé, 1998). Thus, the attempts to revive the flagging fortunes of Dutch gas - through belated offers of additional gas to foreign customers - have achieved only modest success. A recovery from the 1991 production low has been secured (see Table 2), but the national share of the relevant European market has, nevertheless, hardly increased. The national reserves to production ratio, meanwhile, remains at a generous \pm 25 years, while technological advances and new investments (Schweppe, 1999) appear to remain capable of extending the productive life of the Groningen field beyond the end of the first quarter of the twenty-first century: and beyond a $300010^{9} \mathrm{~m}^{3}$ of total recovery, compared with the reserves declaration in year one of production of only $110010^{9} \mathrm{~m}^{3}$ (see Fig. 3).

It was perhaps the eventual recognition by the mid1990s of the economically sub-optimal results from the country's exploitation of its gas resources - and the irrational combination of a limited market development with the simultaneous existence of a resource "overhang", that really motivated the fundamental reappraisal of the organization and structure of the Dutch gas industry then undertaken, rather than the threat of EU pressures for the eventual liberation of the sector.

\section{Liberalization}

Much to the surprise of the European energy community, the Third White Paper on Energy ( EZ, 1996) contemplated a fundamental change to the traditional 


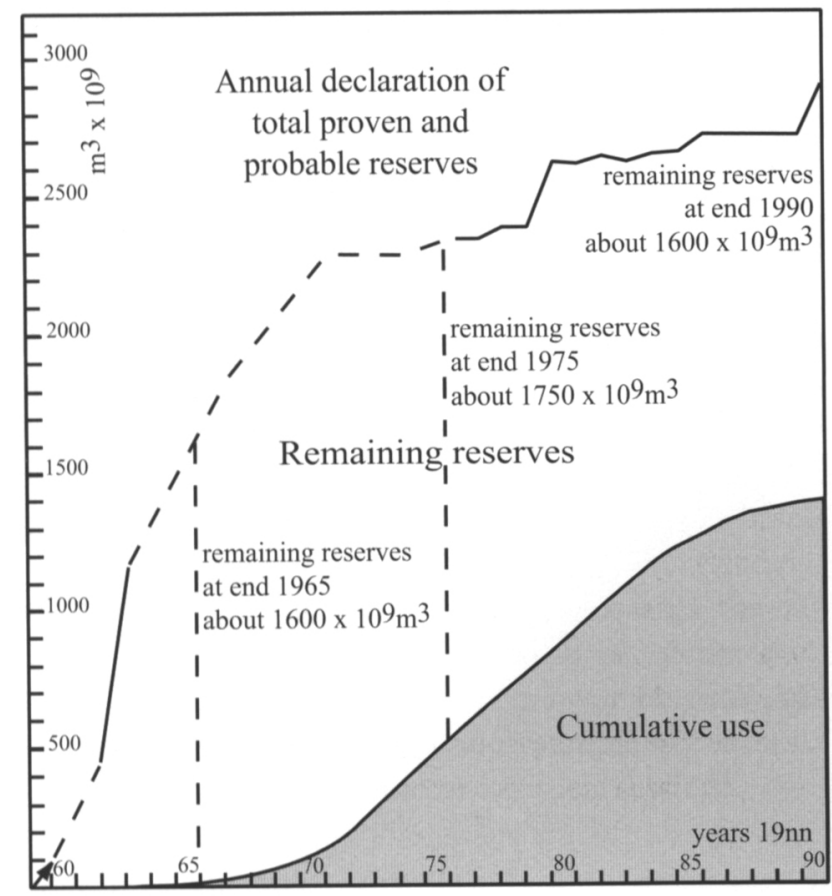

Fig. 3. The Groningen gas field: Cumulative production, 1965 1990 and the evolution of estimates of recoverable reserves from 1959 - 1990 (Odell 1991).

organization and the operation of the Dutch gas industry. The 1998 draft Gas Law (EZ, 1998) provided that customers would have free choice regarding their gas supplier(s). Large consumers, accounting for around $46 \%$ of Gasunie's home market sales, were explicitly allowed to seek alternative suppliers immediately. In 2002, medium sized users, representing $16 \%$ of the market, will follow. Eventually, in 2007, the small users will be allowed to shop around freely.

Gasunie's right of first refusal to Dutch gas producers has been withdrawn. New suppliers and traders have been given the right of negotiated access to the transport and distribution systems. Gasunie and the distribution companies will have to establish Chinese walls between their trade and transport activities and publish separate indicative prices for the services provided.

The basic structure of the industry, with a key role for Gasunie and De Maatschappij/NAM - including a cross shareholders-ship - is maintained. This is because, as is argued, it provides scale and organizational advantages and allows for the continued co-ordination of gas sales and purchases from Groningen and the small fields (EZ, 1998, p. 18-22). This raises the question whether and how the changes in the trade regime can be reconciled with the core elements of current Dutch policy, viz. the maintenance of state and private revenues (the aardgasbaten), the small fields policy and the balancing function of the Groningen field and the depletion policy.

To appreciate the consequences, it is essential to take note of the institutional and financial framework of the Dutch gas industry. Gasunie 'passes on' most of its revenues to its suppliers, NAM and the other gas producers. Its operational costs are less than 1 cent $/ \mathrm{m} 3$ and its shareholders receive a fixed annual dividend of only Dfl 80 million. In 1997 Gasunie's total requirements were $8410^{9} \mathrm{~m}^{3}$, of which around 3.4 $10^{9} \mathrm{~m}^{3}$ was imported. $29.410^{9} \mathrm{~m}^{3}$ was purchased from Groningen and $50.410^{9} \mathrm{~m}^{3}$ from the smaller Dutch fields (Gasunie, 1997). The gas produced from smaller fields is being purchased with priority, in relatively constant volumes, and at an 'adequate' price. The daily and seasonal balance is met by purchases from Groningen. This implies, that a fall in Gasunie's overall volume of sales will bring about an immediate decline in production at the Groningen field (Correljé, 1998, p.145-158).

The net revenues of the producers are split between the companies (around 30\%) and the state (70\%). Crucial, however, is that the production costs in Groningen are estimated at less than 1 cent $/ \mathrm{m}^{3}$, while at the larger off-shore and on-shore fields these costs are respectively around 7 and 4 cent $/ \mathrm{m}^{3}$ (Kunneke et al., 1998). This implies, that the private and state revenues on Groningen production are much larger than those on production elsewhere and that - consequently - the parties involved have an enormous interest in maintaining output at Groningen. Therefore, the need to primarily protect its sales volume must lie at the heart of Gasunie's strategy. Note that, in 1996, the overall production objective was set at around 80 $10^{9} \mathrm{~m}^{3}$ annually up to 2010 .

Yet, the first supply contracts without Gasunie involvement have been signed. Trading affiliates of Dutch distribution companies import UK gas, through their own Zebra pipeline and the Interconnector - and not through the Gasunie system. Gasunie counts with a loss of around $20 \%$ of its sales over the mid-term, although the Minister of Economic Affairs at that time, Wijers stated, that he was fully confident that Gasunie would be able to underbid alternative suppliers. Gasunie foresees a loss of around $10 \%$ of its throughput for 1999 (Volkskrant, 1996; Gas, 1997; NRC, 1999; Het Financieële Dagblad, 1998), while it will have to cope with competitive prices in its home market as well as abroad.

These developments may prompt a revision of 
Gasunie's marketing strategy, in which compensation for falling sales and/or revenues is sought through an increase in the exports of Dutch gas. While the home market is saturated, by and large, the current development of gas demand in Europe certainly provides Gasunie with an opportunity to - at least - stabilize its overall sales volume. Yet, so far, gas exports have been restricted, as a consequence of the requirement to maintain sufficient proven reserves to satisfy the Netherlands' consumption over a 'rolling' 25 years' period ( EZ, 1996, p. 133; EZ, 1997, p. 18); Algemene Energie Raad, 1998, p. 10.).

Gradually, though, it is accepted that this requirement is excessive - not the least by Gasunie (Verberg, 1998.). The draft Gas Law states that Gasunie can no longer be held responsible for the long-term security of supply for importing consumers, while it is also explicitly stated that "Dutch gas cannot be reserved primarily for Dutch consumption". It can be expected, that this revised view is bound to meet a lack of understanding from the Dutch public, which has been brought up for 25 years with the idea, that Groningen gas is a scarce asset and that it should be reserved primarily to Dutch consumers. Nevertheless, an enhanced supply position for Gasunie would be supportive to the further penetration of gas in Europe, with the associated advantages regarding environmental effects and efficiency in energy use. If combined with flexible supplies, it could stimulate the creation of additional outlets for long distance high load-factor gas from Norway, Russia and elsewhere (including supplies by the foreign affiliates of Gasunie's own shareholders Shell and Exxon in North-Germany, Norway and the UK.). The storage facilities in depleted reservoirs, in Alkmaar (with Amoco), Langelo, Grijpskerk and above all - the flexible production at Groningen are instrumental in this respect (Energie Nederland, 1998, p. 8).

We conclude, that the liberalizing steps taken by the Dutch government, so far, and the changes that can be observed in Gasunie/NAM's strategy, may do justice to the magnificent low cost supply potential of the Groningen field, ultimately. The apparent revision of the concept of long-term supply security is essential in this respect (gas exports, that have to be compensated by imports, yield relatively moderate profits, because the crucial up-stream profits flow to foreign producers and governments). Instead of selling limited volumes at high prices, Gasunie will have to be allowed to return to the European market as an active and strategic player - unconstrained by an increasingly burdensome limitation of exports.
The benefits of the liberalization of the Dutch gas industry - as a unique element of international competitive advantage to the Dutch economy - to the smaller and medium Dutch consumers will depend on the manner in which the new Gas and Mining Laws and the Dutch competition authority will enforce third party access to transportation, storage and handling facilities. Yet, it is precisely through its control over these storage facilities, that Gasunie is in the position to protect its home market. By withholding alternative suppliers access to these essential facilities the market will remain incontestable and thus the smaller and medium sized consumers will hardly experience the potential benefits of liberalization ( Energie Nederland, 1999, p. 9)

Eventually, however, extending the benefits of liberalization to these smaller users may turn out to be a political necessity. Indeed, otherwise, it will be rather difficult to explain the newly accepted 'non-scarcity' paradigm and an expansion of Gasunie's international role, given the long-time deliberately fostered perception of the need - or even the right - of Dutch users to be supplied with Dutch natural gas far into the next century.

\section{References}

Algemene Energie Raad, 1998. Liberalizatie van de gas sector.

Correljé, A.F., 1998. Hollands Welvaren: De geschiedenis van een Nederlandse bodemschat, TeleacNOT, Hilversum.

Energie Nederland, 1998. Nummer van 8/12/1998: 8.

Energie Nederland, 1999. Nummer van 18/3/1999: 9.

EZ (Ministry of Economic Affairs), 1996. Third White Paper on Energy Policy.

EZ, 1997. Gasstromen. Ministerie van Economische Zaken, Directoraat-Generaal voor Energie, Den Haag.

EZ (Ministry of Economic Affairs), 1998. Regels omtrent het transport en de levering van gas (Gaswet): MEMORIE VAN TOELICHTING en VOORSTEL VAN WET.

Gas, 1997. Krant van Juni 1997, 13.

Gasunie, 1997. Jaarverslag Gasunie.

Het Financieele Dagblad, 1998. Krant van 3//11/1998.

Kunneke, R.W., Arentsen, M.J., Manders, A.M.P. \& Plettenburg, L.A., 1998. Marktwerking in de gasmarkt, Beleidsstudies Energie, Den Haag, DGE, Ministerie van Economische Zaken, 19: 105.

NRC, 1999. Krant van 5/1/1999.

Odell, P.R., 1969. Natural Gas in Western Europe: a Case Study in the Economic Geography of Resources, De Erven F. Bohn, Haarlem.

Odell, P.R., 1973. Het Nederlandse Aardgastekort: onbeantwoorde vragen en een alternatieve hypothese. Economisch Statistische Berichten 58e Jaargang, no.2900: 422-426.

Odell, P.R., 1975. The Western European Energy Economy, Challenges and Opportunities, Athlone Press, London.

Odell, P.R., 1979. Constraints on the Development of Western Europe's Natural Gas Producing Potential in the 1980s. OilGas 5/3: 21-30. 
Odell, P.R., 1984. Constraints on the Development of Natural Gas resources with Special Reference to Western Europe. In: C. Campbell Watkins and L. Waverman (eds): Adapting to Changing Energy Prices. Oelgaschlager, Gunn and Hain, Cambridge.

Odell, P.R., 1988. The West European Gas Market: the Current Position and Alternative Prospects. Energy Policy 16/5: 480-493.

Odell, P.R., 1991. Global and regional Energy Supplies: recent Fictions and Fallacies Revisited. EURICES, Rotterdam 1991.

Odell, P.R., 1992. Prospects for Natural Gas in Europe. The Energy Journal 13/3: 41-62.
Odell, P.R., 1995. The Cost of Longer-Run Gas Supply to Europe. Energy Studies Review 7/2: 94-108.

Odell, P.R., 1997. Europe's Gas Consumption and Imports to Increase with Adequate Low Cost Supplies. Energy Exploration and Exploitation 15/1:35-54.

Schweppe, F., 1999. Groningen Long Term: project van lange adem. PetroChem, 2/feb: 16-21.

Volkskrant, 1996. Krant van 8/5/1996;

Verberg, G., 1998. Comments. Het Financieele Dagblad 3/11/ 1998. 